た。

\section{分類所見要素 :}

(1)細胞直径

$20 \mu$ 以下（基底層細胞に該当）

$20 \sim 60 \mu$ (旁基底または中間層細胞に該当)

$60 \mu$ 以上（表層細胞に該当）

(2)胞体の染色性，緑色または橙色

(3) $\mathrm{N} / \mathrm{C}$ 比.

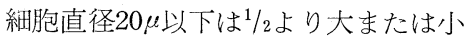

細胞直径 $20 \sim 60 \mu$ は $1 /$ より りまたは小

細胞直径 $60 \mu$ 以上は $1 / 5$ より大または小

(4)核膜円滑または不均等肥厚 (核壁質増多)

飯島 ${ }^{4)}, \mathrm{Kraus}^{5)}$, 田島ら ${ }^{6)}$ の報告の如く, 核壁質增 多,すなわち, クロマチンの核膜側への移動が新鮮 紐胞と変性細胞の主要な鑑別点となる。たとえば, 同一症例で臸膏（変性細胞）と病巣察過材料（新鮮 細胞）を比較すると表 1 の如くである。

表 1 腟膏と病巣塗抹細胞における核膜の比較 （子宫胵部非角化扁平上皮癌）

\begin{tabular}{|c|c|c|c|c|c|c|}
\hline \multirow[t]{2}{*}{ 症例 } & 胵 & 高 & \multicolumn{4}{|c|}{ 病 巣 塗 抹 } \\
\hline & I III III & 平均 (\%) & I & II & III & 平均 (\%) \\
\hline 滑 & $\begin{array}{llll}57 & 24 & 86\end{array}$ & 56 & 73 & 100 & 00 & 91 \\
\hline 核壁質增多 & $43 \quad 76 \quad 14$ & 44 & 27 & 0 & 0 & 9 \\
\hline
\end{tabular}

(田島ら $\left.{ }^{6)}, 1968\right)$

(5)クロマチン（図示）

細一顆粒が細かく，分布は均等 (細顆粒)，または クロマチン糸は細く分布均等で間隔狭い(細網) (日本病理学会形態学コード分類6303微細分散 染色質に該当).

粗一系の間隔が広く，太いのを混ず，分布は不均等 (粗網, 梁)（日本病理学会形態学コード分類 6302, 粗分散染色質に該当).

顆一顆粒が大きく,クロマチン糸ほとんど認められ ない，核膜も分明でないことがある。

液一濃縮, 融解, 破砕等の高度の変性を示す（日本 病理学会形態学コード分類6305, 染色質融解に 該当).

以上 4 種のクロマチンパターンは重層扁平上皮の実 験観察（山岸，田島1967)7から得られたものである。 すなわち正常の重層扁平上皮は基底層, 中間層, 表層 と成熟すると共に変性脱落する，基底層においてクロ マチンは細，中間層で細が隇少し粗，顆，液がみら れ，表層で粗または液である。中間層, 表層にみられ
る．粗，顆，液は変性核のクロマチンである。

(6)観察細胞 上記の細胞直径，胞体の染色性 $\mathrm{N} / \mathrm{C}$ 比, 核膜，クロマチンの 5 要素を標本上にみられるすべて の扁平上皮細胞について観察し，いずれかの細胞形態 に分類した、いわ河る「巽型的」とか「正常範囲をこ えた」というような考えを，いっさいご破算にして， 標本上のすべての細胞について所見をとった。

\section{3. 疾患別細胞像 (表 2$)$}

(1)正常剝離扁平上皮細胞像

細胞の記載は細胞直径, 胞体の染色性, $\mathrm{N} / \mathrm{C}$ 比, 核 膜, クロマチンの順とし，以下のすべて同様とした。

表 2 子宮腟部病変に出現する細胞

正常・炎症に出現する細胞 上記細胞を除外した細胞

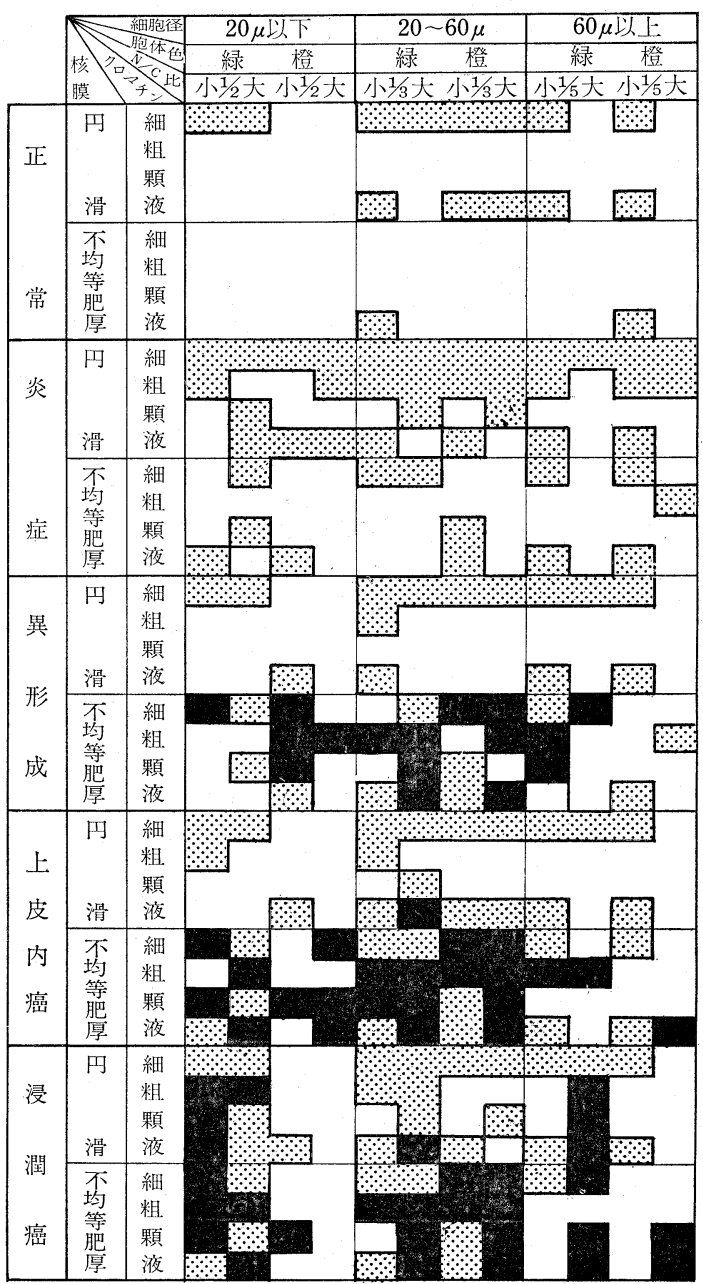


表 3

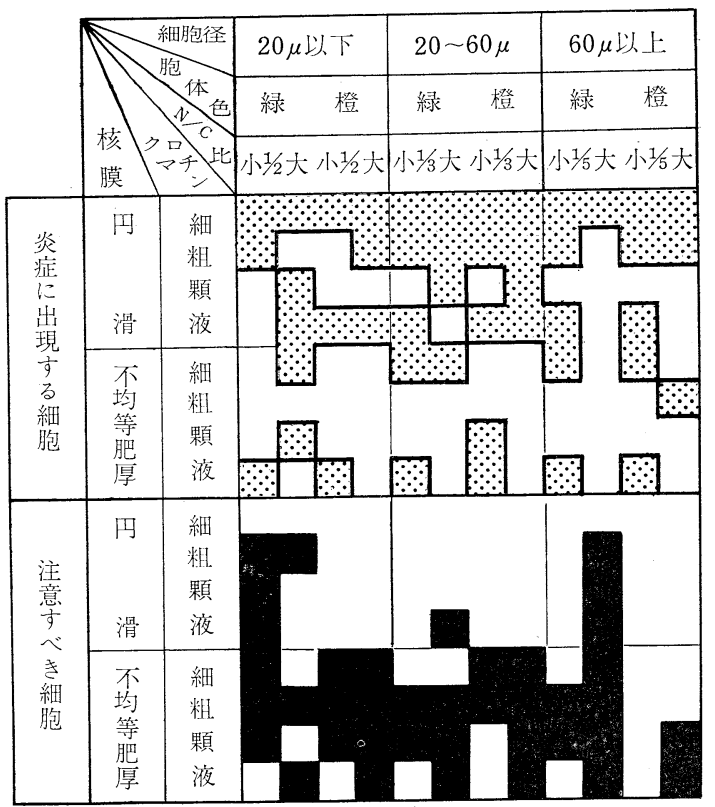

表 4 異形成 癌に出現する細胞一炎症時細胞除外一

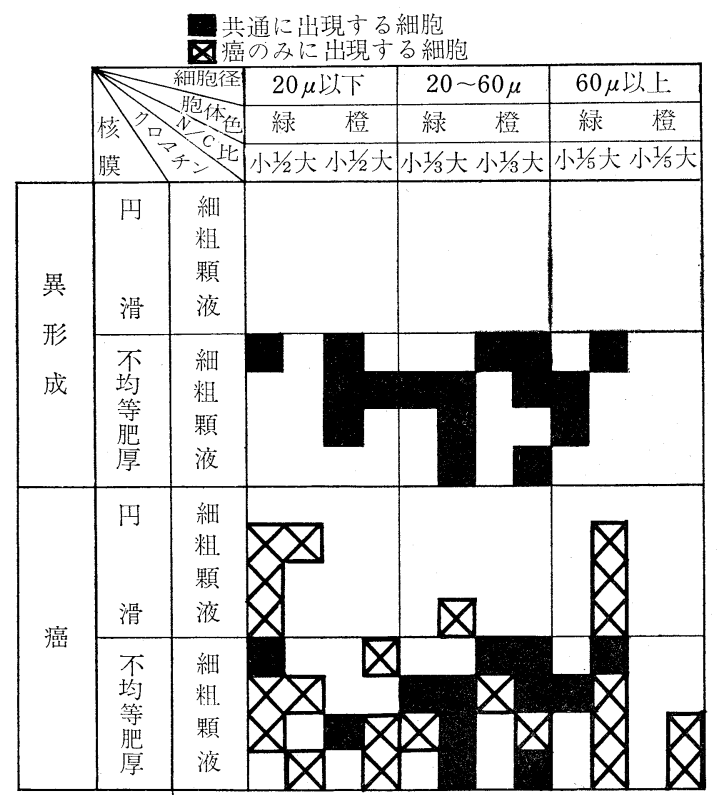

$20 \mu$ 以下

。緑・大, 小・滑・細

$20 \sim 60 \mu$

。緑, 橙・大, 小・ 滑・細

。緑・小・滑・液

。橙・大, 小・円滑・液

。緑・小・不均等肥厚・液

$60 \mu$ 以上
。緑, 橙・小・円滑・細, 液

。橙・小不均等肥厚・液

上記の如く細胞直径は様々である，胞体は $20 \mu$ 以下 は緑色のみ, $20 \mu$ 以上では緑, 橙色共ある. N/C比は 大小共あるが， $60 \mu$ 以上ではすべて $1 / 5$ 以下である．核 膜はほとんど円滑であるが，一部不均等肥厚がみられ る.これらの細胞はすべて N/C 比小，クロマチン液 である。クロマチンは細または液であり，液は大部分 N/C 比小の細胞にみられる。

(2)慢性炎症剥離扁平上皮細胞像

$20 \mu$ 以下

。緑, 橙.大, 小・田滑・細

。緑・小. 円滑・粗

。橙・大・円滑・粗

。緑・大・円滑・頼

。緑・大・ 只滑・液

。橙・大，小・円滑・液

。緑・大・不均等肥厚 - 細, 顆

。緑, 橙 - 小不均等肥厚 - 液

$20 \sim 60 \mu$

。緑, 橙・大, 小. 円滑 - 細, 粗

。緑, 橙・大・円滑 - 顆

。緑, 橙・小・円滑・液

。緑・大, 小・不均等肥厚・細

。橙・小不均等肥厚・顆, 液

$60 \mu$ 以上

表 5 上皮内癌 浸潤癌に出現する細胞 一炎症時細胞除外一

共通に出現する細胞

8浸潤癌のみに出現する細胞

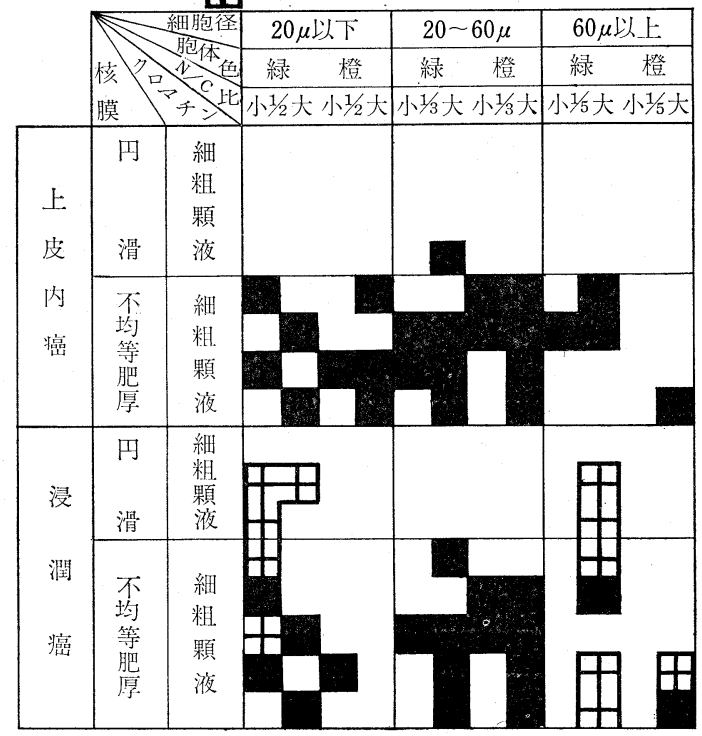



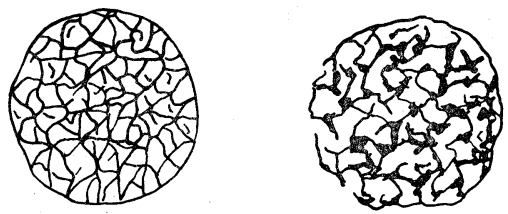

細
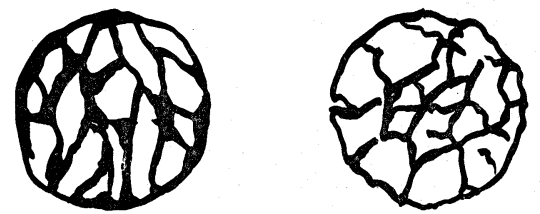

粗

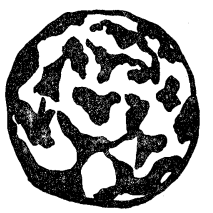

顆
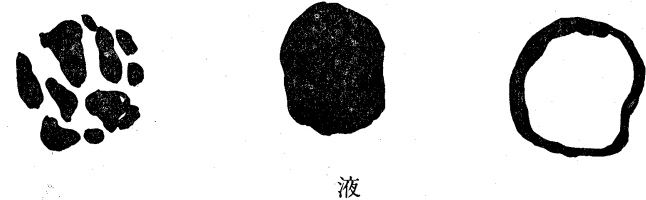

図1クロマチン模式

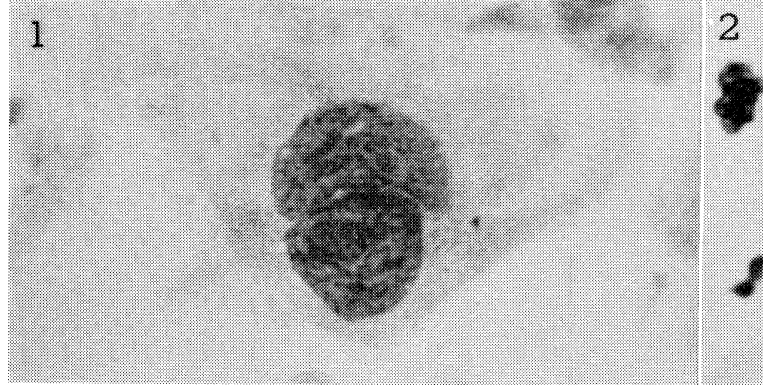

図2クロマチン細 (1)

核壁質增多を認めず（核緑円滑）

炎症から浸潤癌まですべての疾患に出現する

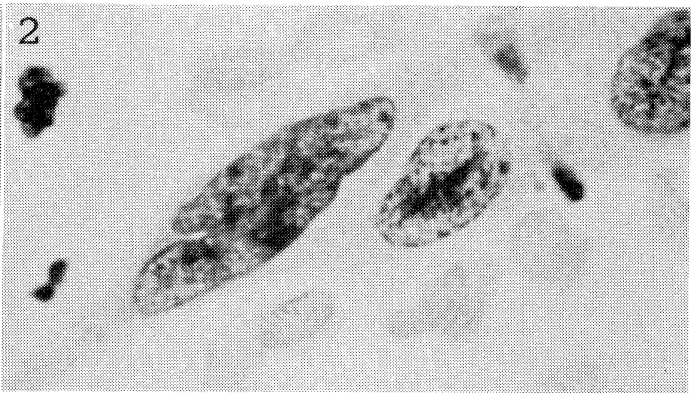

図3クロマチン細 (2)

核壁礩增多を認を

Dysplasia（異形成）以上の病変に出現する

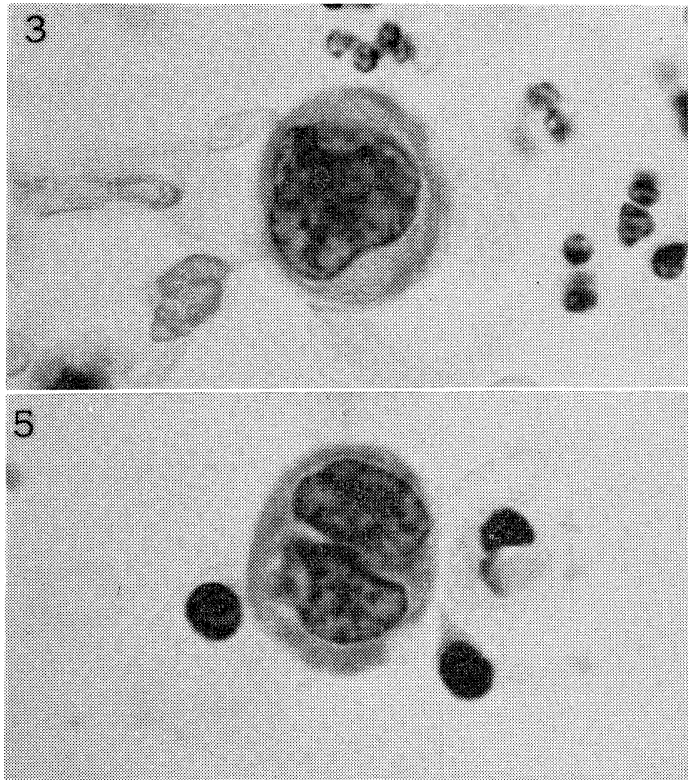

図4 クロマチン粗 $(3,5)$

核壁質增多少し．主として漫潤癌にのみ認めるが， 稀に炎症において出現することあり
4
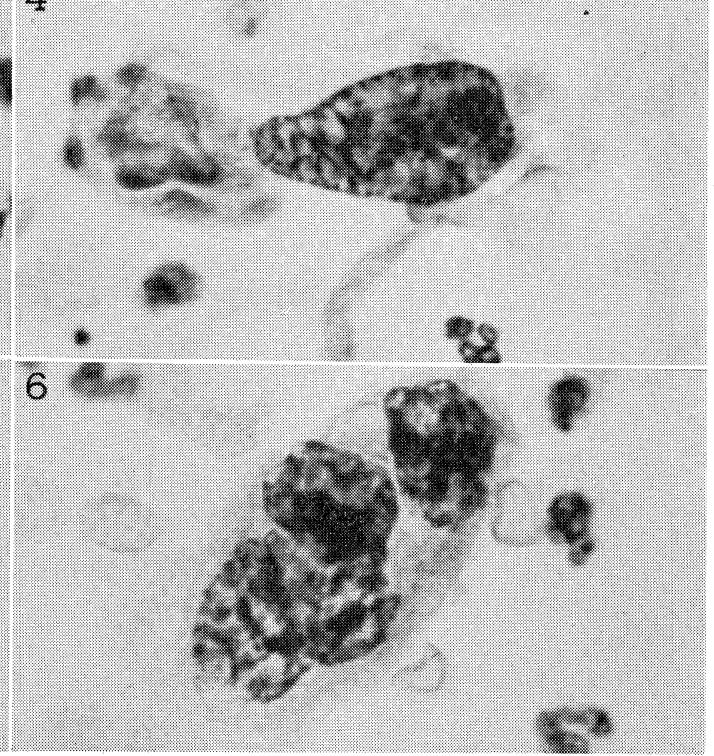

図 5 クロマチン粗 $(4,6)$

核壁質增多著明異形成以上の病変に出現す る 


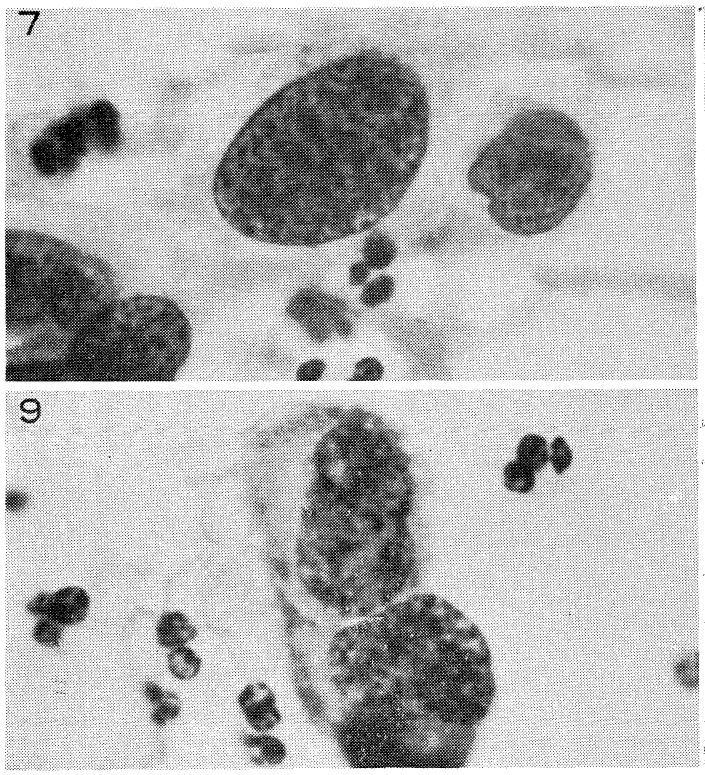

図6クロマチン顆 $(7,9)$

核壁質增多極めて少し, Ca. in-situ(上皮内癌)

以上に出現するが稀に炎症においても認める

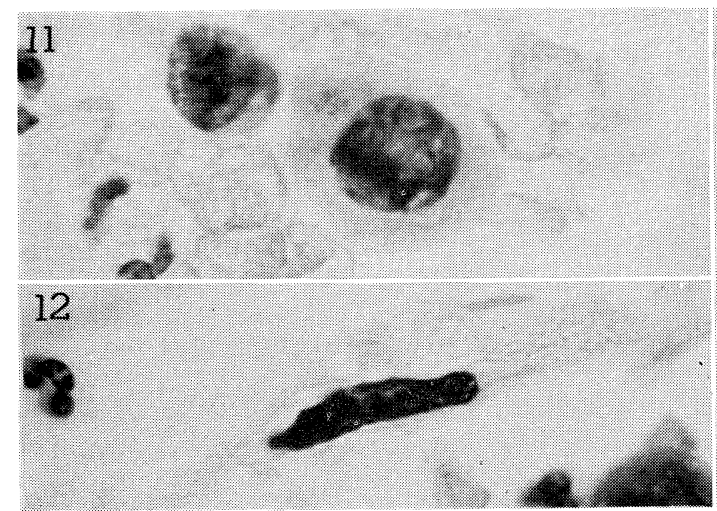

図 8 クロマチン液（融解一11 濃縮一12） 共に異形成以上に出現する
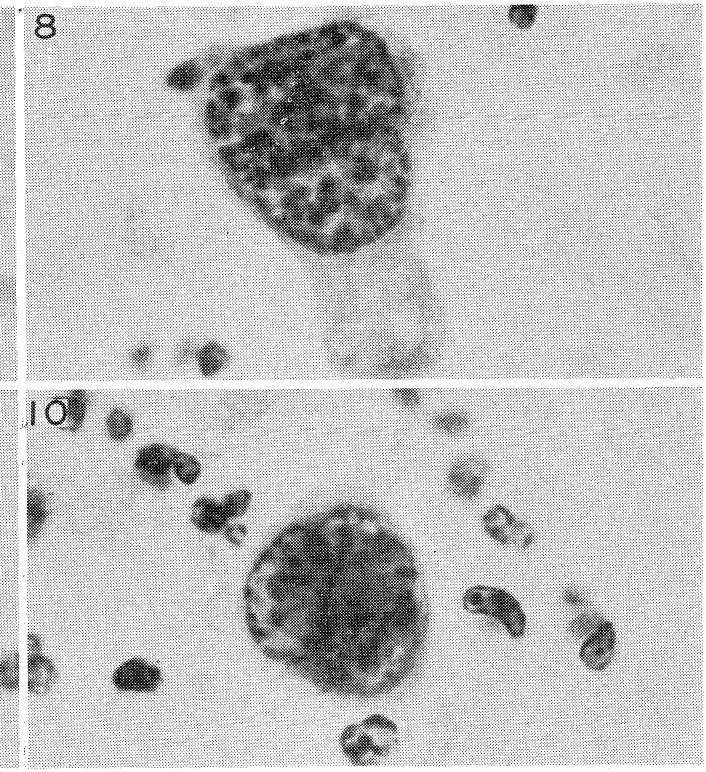

図7クロマチン顆 $(8,10)$

核壁質增多严り，異形成以上の病変に出現 する

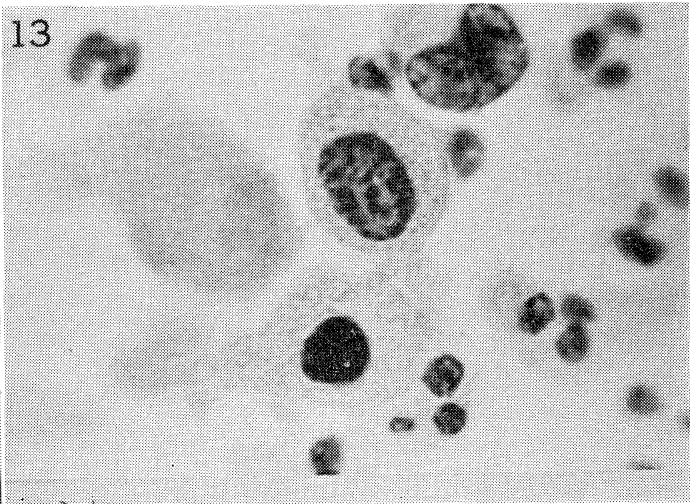

図 9 上からクロマチン粗（13）

$$
\text { " 顆 }
$$

左に核消失

これだけのパターンの組合わせは主と して浸潤癌の所見である

る、N/C 比大小ともにある。核膜は円滑が多いが， $\mathrm{N} / \mathrm{C}$ 比小には不均等肥厚もみられる。クロマチンは 核膜円滑には細，粗，顆，液がみられるが，不均等肥 厚の核膜では細, 液が多く粗, 顆は少い。液のみられ る細胞の N/C 比はほとんど小である。また顆は N/C 比大の細胞にみられる。

(3)異形成剩離扁平上皮細胞像

\section{$20 \mu$ 以下}

。緑・大, 小・円滑・細 
。橙・小・円滑・液

。緑・小・不均等肥厚・細

。緑・大・不均等肥厚・細, 顆

。橙・小・不均等肥厚・細, 粗, 顆, 液

。橙・大・不均等肥厚・粗

$20 \sim 60 \mu$

。緑, 橙・大, 小・円滑・細

。緑・小・円滑・粗, 液

。緑・小・不均等肥厚・粗, 液

。緑・大・不均等肥厚・細, 粗, 顆, 液

。橙・小・不均等肥厚・細, 顆, 液

。橙・大・不均等肥厚・細, 粗, 液

$60 \mu$ 以上

。緑, 橙・小・円滑・細, 液

。緑・大・円滑・細

。緑・小・不均等肥厚・細, 粗, 顆, 液

。緑・大・不均等肥厚・細

。橙・小・不均等肥厚 $\cdot$ 液

。橙・大・不均等肥厚・粗

以上の如き細胞が出現する。これらの細胞から, 正常 および炎症時に出現する細胞を除外すると，表 2 の黒く つぶした細胞群が残る。この細胞群の特徴は，すべて核 膜の不均等肥厚を伴うことである。また $\mathrm{N} / \mathrm{C}$ 比は $60 \mu$ 以下の細胞はほとんど大である.クロマチンは細もみら れるが，粗・顆・液を含み多様である。

(4)上皮内癌洜離扁平上皮細胞像

\section{$20 \mu$ 以下}

。緑・小・滑・細, 粗

。緑・大・円滑・細

。橙・小・滑・液

。緑・小・不均等肥厚・細, 顆, 液

。緑・大・不均等肥厚 $\cdot$ 細, 粗, 顆, 液

。橙・小・不均等肥厚・顆

。橙・大・不均等肥厚・細, 顆, 液

$20 \sim 60 \mu$

。緑・小・滑・細, 粗, 液

。緑・大・円滑・細, 顆, 液

。登・大, 小・円滑・細, 液

。緑・橙・大, 小不均等肥厚 - 細, 粗, 顆, 液 $60 \mu$ 以上

。緑, 橙・小・円滑・細, 液

。緑・大・円滑・細

。緑・小・不均等肥厚・細, 粗, 液

。緑・大・不均等肥厚・細, 粗

。橙・小・不均等肥厚・細, 液

。橙 $\cdot$ 大 $\cdot$ 不均等肥厚 $\cdot$ 液
以上の如く胞体の大きさは様々である。また胞体の染 色性, N/C 比も様々である。核膜円滑の細胞のクロマ チンは大部分細または液である。核膜不均等肥厚の細胞 のクロマチンは粗, 顆を含み多様である.

(5)浸潤癌剝離扁平上皮細胞像

\section{$20 \mu$ 以下}

。緑・大, 小・円滑・不均等肥厚・細, 粗, 顆, 液

。橙・小・円滑・液

。橙・小・不均等肥厚・顆

$20 \sim 60 \mu$

。緑・小・滑, 不均等肥厚・細, 粗, 液

。緑・大・ ・滑, 不均等肥厚・細, 粗, 顆, 液

。橙・小・田滑・細, 液

。橙・大・円滑・細, 顆

。橙・大, 小・不均等肥厚 - 細, 粗, 顆, 液

$60 \mu$ 以上

。緑, 橙・小・円滑・細, 液

。緑・大・円滑 $\cdot$ 細, 粗, 顆, 液

。緑・大, 小・不均等肥厚・細

。緑, 橙・大・不均等肥厚・顆, 液

以上の如く細胞形態は多様である。特に胞体緑色の細 胞に各種クロマチンパターンを認める. 胞体隥色の細胞

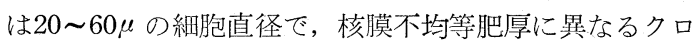
マチンパターンを認める.

\section{4. 核形態別所見}

(1)核膜一正常または炎症の紐胞は円滑が大部分である. 少数不均等肥厚がみられるが, この際クロマチンは細 または液である。異形成, 上皮内癌, 浸潤癌の細胞は 不均等肥厚が多くみられ, 円滑の場合はクロマチンは 大部分細または液である.

(2)クロマチン

細一正常にも各病変にもみられる。しかし, 核膜不均 等肥厚で細は正常にはみられない，炎症以上の病 変でのみ出現する.

粗一正常には全くみられず, 炎症以上の病変に出現す る. 特に核膜不均等肥厚のある場合は, 異形成以 上の病変にのみ出現する.

顆一正常には全くみられず, 炎症以上の病変に出現す る。また核膜不均等肥厚の細胞は, 異形成以上の 病変に多く出現する。

液一各病変に出現する。正常または炎症時には $\mathrm{N} / \mathrm{C}$ 比小の細胞に限りみられる。 $\mathrm{N} / \mathrm{C}$ 比大で, 液の クロマチンは異形成以上の病変にみられる。

\section{5. 疾患別細胞像の比較}


(1)正常および炎症時の扁平上皮細胞

。表 3 に炎症に出現する細胞としてまとめた

。細胞直径 種及

。胞体の染色性 種々

。 N/C 比種々 ただし核膜不均等肥厚の認められる 細胞では $\mathrm{N} / \mathrm{C}$ 比小が多い.

○クロマチン 種々 ただし核膜円滑の細胞では細，粗 液が多く，核膜不均等肥厚の細胞 では細，液である。

。核膜 円滑が多い. 少数不均等肥厚も認められる.

(2)異形成掞よび癌持の扁平上皮細胞

表 3 に注意すべき細胞としてまとめた。すなわち，異 形成, 上皮内癌, 浸潤癌に出現した細胞のうち, 正常お よび炎症時の細胞を除外した細胞を表 3 に黒く妁つふ した．これら黒くつぶした細胞の出現は, 異形成以上の 病変を考えさせる。集団検診では, これらの細胞の出現 があったら，一灾生検か，follow up すべきであろう.

これらの細胞は先の報告 (田島, 山岸8) ${ }^{8}$ ) の如くであ る. すなわち, 出現細胞数は, 異形成で 5 ２0個平均 14個，上皮内癌で $30 \sim 100$ 個以上，平均72個，浸潤癌は すべて 100 個以上， 1 枚のプレパラートに出現する.

。 $\mathrm{N} / \mathrm{C}$ 比はいずれの病変とも 9 割以上が大である.

。細胞直径, 各病変とも 6 割以上 $20 \sim 60 \mu$ である。浸潤 癌では他の病変 (異形成, 上皮内癌) に比し $20 \mu$ 以下 の細胞の出現数が多い。また, 同一症例における細胞 直径のバラッキは異形成では $60 \mu$ 以下のみ, $20 \mu$ 以上

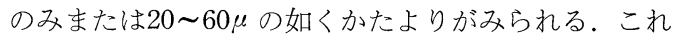
に比し上皮内癌, 浸潤癌ではすべての大きさが同一標 本上に認められる.

○クロマチン 異形成では細が 8 割以上, 顆および粗は 各 1 割程度である。上皮内癌では細 4 割, 顆 5 割を占 め, 残りが粗, 液である. 浸潤癌ではほぼ上皮内癌と 同様であるが，粗の増加が認められる。

(3)異形成と癌時の扁平上皮細胞像の差

表 4 に示した如くである。炎症および正常時の細胞を 除外した細胞を表にまとめた。×印の細胞群は異形成に は出現しない細胞である。この細胞の出現をもって晎形 成と癌を区別する。これらの細胞は $20 \mu$ 以下で緑色, ま たは，核膜の不均等肥厚を伴う細胞， $60 \mu$ 以上では緑色

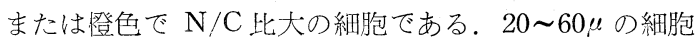
は異形成と癌であまり差はみられない.

(4)上皮内癌と浸潤癌の細胞像の差

表 5 に上皮内癌, 浸潤癌に出現する細胞のうち, 正常お よび炎症の細胞を除きまとめた。 $20 \mu$ 以下および $60 \mu$ 以 上の細胞に差を認める。すなわち, $20 \mu$ 以下, 緑, N/C 比小の細胞抢よび $60 \mu$ 以上, 緑, $\mathrm{N} / \mathrm{C}$ 比大の細胞は上皮
内癌では認められない。

出現細胞数およびその大きさの分布, 症例におけるバ ラッキ， $\mathrm{N} / \mathrm{C}$ 比では両者に差はない.

クロマチン構造の出現の頻度に多少差を認める。すな わち, 細, 顆, 液はほぼ同程度であるが，粗は浸潤癌で は 1 割程度みられるのに比し, 上皮内癌では 0.5 割程度 である。

\section{6. 考按}

「異型的」という言葉を細胞診では従来用いて来た. しかし異型の概念は，研究者により様々である ${ }^{9}$.

現在のところ, 癌細胞の定義は, 形態学的にも生化学 的にも, どれか一つの要素の有無のみでは決定されてい ない. 螢光を用い要素の定量化を行なっても, また, 形 態学的要素の訮細な測定を行なっても, 腫瘍を構成して いる癌細胞の変暴の前には傾向差を明らかにするにとど まり，細胞個々の同定には参考所見とするのみである. 癌細胞の, 従来重大な鑑別点とされている核の腫大, 核 の渦染性等は甲状腺, 副腎等の変性細胞でもみられ ${ }^{10)}$, また，照射等治療によっても必発する変化である ${ }^{11)}$. そ こで, 所見要素の詳細な測定が癌細胞診断に役立たぬな ら，それら所見を合成して傾向差を大とし，また，核の 変性所見を実験的に把握し, 癌細胞の質的差を見出そう とした。

所見要素は先に報告6) した如く，クロマチンを中心と して，なるべく具体的に客観的にとらえることが出来る ようにした。

この試みは，すでに $\operatorname{Kern}^{12)} に よ り$ 行なわれている. 異型的な細胞を，Dyskaryosen と Atypische Zellen に分けた.さらに前者を oberflächliche Zellen, mitllere Zellen 抢よび tiefe Zellen に3 分し, 後者を uniform と polymorphに 2 分した。これらの細胞を形態の類似 する細胞と鑑別し，上記細胞の出現で einfach atypisches Epithel, Carcinoma in-situ 掞よび Carcinomaを 診断した.この分類は, 多分に観念的な傾向があり, 実 際には稀にしか見られない症例も，大多数の症例も同列 に扱っている，すなわち，Ca.in-situ の際に出てくる細 胞が, Dyskaryosen の oberflächliche Zellen のみと か，それに mitllere Zellen が加わる場合があるとして いるが，実際これらの細胞の出現のみでは Ca.in-situ と Dysp'asia の鑑別は困難に思う。また，Ca.の場合 女非角化型扁平上皮癌や, 未分化癌の場合, 常に, polymorph の atypische Zellen の出現しない場合があ る。すなわち観念的な部分が多く含まれ，実用上は不便 なことがある。

また, Graham ${ }^{13)}$ も Kern と同様の記載をしている. 
すなわち, Dysplasia は Dyskaryotic cell, Ca. in-situ は the third type differentiated squamous cell, また invasive のCa. の場合は, undifferentiated malignant cell または differentiated malignant cell の出現で診 断している.しかし， the third type differentiated squamous cell $と$ undifferentiated malignant cell の 差を決定しているのは，核でなく胞体によっている。こ れは胞体の融解変性した場合に決定されたもので, 新鮮 な細胞を判定するには役立たない。

上述した如く，変性所見により細胞を判定しているこ とが多い．また腫場を構成する腫瘍細胞は生物学的性状 の異なるものが混在していることが考兄られる.

今回所見要素をバラバラにし，それを合成した総合所 見に細胞を当てはめた，結果は Ca. の場合，種々の変 性細胞を含むことが判明した。

最終的には可能か否かわからないが，1個の細胞のみ の所見をもってして各疾患の診断に到達したい希望があ るが, 現在までのところ, 上述した如く,ある程度以上の 細胞数についての所見を各要素別に分析し合成し, 出現 の組合わせによって診断する線まで究明した。しかし， この研究を通じて子宮腟部境界領域病変に出現する細胞 像の差を確めた。

今後症例を多くし，Papanicolaou 染色のみの所見で なく，他の細胞学的方法を用い，検討を加えること，お よび各所見要素をさらに分析し, 癌細胞の生物学的性状 を研究して行きたいと考える。

\section{7. 結 語}

(1) 子宮胵部境界領域病変を材料とし, 所見要素を分析

し，組合わせ，1個の細胞形態のパターンとして把握

し，標本上のすべての扁平上皮細胞を分類した。

(2)正常, 炎症, 異形成, 上皮内癌, 浸潤癌の間に細胞像 の差異を見出した。

(3)正常，炎症より異形成に，異形成より上皮内癌に，上 皮内癌より浸潤癌に変性細胞核が多く認められた。

(4)癌の同一標本上には新鮮細胞核と, 变性細胞核の種々 のパターンが認められた。

(5)所見の組合わせによる表を表 2 , 表 3 , 表 4 , 表 5 に 示した。

この論文の要旨は第 7 回, 第 8 回, 日本臨床細胞学会 総会にて報告した。

稿を終わるにあたり，日頃御指導賜わる国立がんセン 夕一臨床検查部木村蔀代二部長に深謝し, 材料の御便宜 をいただいた，婦人科諸先生，組織病理研究室各位に謝
意を表します。また，終始，助言して下さった細胞診田 島基男医長他諸兄姉に感謝いたします。

な抢，本研究にあたっては，厚生省がん指定研究「が 几細胞の形態学的䛦断方法の開発に関する研究」班（班 長千田信行博士）の御援助を受けたことを記し，班員の 諸先生の御指導御鞭達に謝意を表します。

\section{Summary}

In this study, the cytological findings of the borderline lesions of the uterine cervix were observed Cellular specimens taken from 4 cases of norma cervix, 5 cases of chronic inflammation, 5 cases ol dysplasia, 5 cases of carcinoma in-situ, and 6 cases of carcinoma epidermoid, which cases were proved histologically, were examined.

These specimens were obtained by means of cotton swab from portio vaginalis and fixed in ether and 95 per cent ethyl alcohol solution and stained by the Papanicolaou method.

All squamous cells on the smear were observed on the cell diameter, cytoplasmic staining reaction, nuclear border findings, nuclear cytoplasmic ratio and chromatin pattern.

Results, 1) Different cellular combination were showed on each preparation from normal cervix, chronic inflammation, dysplasia, carcinoma in-situ and carcinoma epidermoid.

2) The smear in cases of carcinoma showed various chromatin types such as "finely reticular or glanular," "grossly reticular", "coasely glanular" and "opaque".

3) As a result of observation on the physiological maturation and serious experimental observation on normal squamous cells, chromatin type such as "grossly reticular" and "coasely glanular" and "opaque" may be due to degeneration.

Cancerous tissue may be composed of various cells which have numerous chromatin figures in maturation and serious degeneration.

\section{文献}

1) Papanicolaou, G.N. : Atlas of exfoliative cytology, Harvard. Univ., 1954.

2) Reagan, J.W., and Hamonic, M.J. : Analytical Study of the Cells in Cervical Squamous-Cell Cancer. Laboratory Investigation., $6: 241 \sim$ 
250, 1957.

3）武井宏澄他：子宮頚部初期浸潤癌の細胞診について 日臨細胞誌 6.4.1967.

4）飯島宗一：海猽脾細胞核の自己融解並びにその所見 を中心とする細胞核の形態学的構造に関する知見補 遺 (I, II). 名古屋医学 : 69巻 4 号, 6 号 1955 .

5) Kraus. H.; Überdie in abgestorbenen Geweben spontan eintretenden Veränderungen. Arch. exp. Path, 22, 174-198, 1883.

6）田島・山岸他：クロマチン形態から見た癌細胞の変 性一細胞診断学との関連を中心に一診断と治療 56 . 2. 1968 .

7) 山岸・田島 : 重層扁平上皮細胞のクロマチンについ て（I）日臨細胞誌. 6.19.1967.
8）田島・山岸：細胞診に於ける所見把握の方式一子宮 境界領域病変を例に一最新医学 23(3)655-670,1968

9）国立がんセンター細胞診室編, 細胞診断学教本, 1967.

10) Koss,L.G. (太田他訳) 細胞診断学, 医学書院. 1964.

11）柴田偉雄他：経時的細胞診による肺癌の化学療法並 びに放射線療法の治療効果の判定について，第25回 日本癌学会総会記事 223.1966.

12) Kern, G; Carcinoma in-situ. Springer-Verlag, Berlin, 1964.

13) Graham, R.M.; The Cytologic Diagnosis of Cancer., W.B. Saunders Company, Philadelphia. 1963. 